\title{
EFFECT OF NOISE EXPOSURE AND USE OF EAR PROTECTION EQUIPMENT ON HEARING IMPAIRMENT AMONG STONE CUTTING WORKERS IN CIREBON, WEST JAVA
}

\author{
Dewi Laelatul Badriah'), Fitri Kurnia Rahim²) \\ ${ }^{1)}$ Study Program in Physical Education, Faculty of Teaching and Education, \\ Unverisitas Majalengka, West Java \\ ${ }^{2}$ Study Program in Public Health, School oh Health Sciences, Kuningan, West Java
}

\begin{abstract}
Background: Stone cutting workers have a risk of hearing loss due to excessive noise levels at the workplace. Hearing loss due to noise exposure in the workplace is a significant health problem with economic consequences. This study aimed to examine the effect of noise exposure and use of ear protection equipment on hearing impairment among stone cutting workers in Cirebon, West Java.

Subject and Method: This was cross sectional study conducted at Filarin Stone Factory, Cirebon, Banten from May to July 2018. A sample of 56 workers was selected for this study by total sampling. The dependent variable was hearing impairment. The independent variables were gender, age, education, marital status, length of work, noise intensity, behavior and knowledge about ear protection equipment. The noise disorder was measured by sound level meter and tuning fork. The other data was collected by a set of questionnaire. The data was analyzed by chi square.

Results: As many as $83.9 \%$ of the workers had hearing impairment. $97.0 \%$ of the workers did not use ear protection equipment. 90.0\% of workers in the workplace with noise level above standard had hearing impairment. 93.5\% of the workers who had worked for over 10 years had hearing impairment. Hearing impairment was associated with lack of ear protection equipment usage $(\mathrm{OR}=36.80 ; 95 \% \mathrm{CI}=3.41$ to 396.72 ; $\mathrm{p}<0.001)$ and length of work hour $(\mathrm{OR}=5.64 ; 95 \% \mathrm{CI}=1.05$ to $30.19 ; \mathrm{p}=0.029)$.
\end{abstract}

Conclusion: Hearing impairment is associated with lack of ear protection equipment usage and length of work hour.

Keywords: noise, workplace, hearing impairment, ear protection, length of work hour.

\section{Correspondence:}

Fitri Kurnia Rahim. Study Program in Public Health, School oh Health Sciences, Kuningan, Jl. Lingkar Kadugede No 2, Kadugede, Kab. Kuningan, West Java. Email: fikura.zone@gmail.com. Mobile: 081320203454.

The $6^{\text {th }}$ International Conference on Public Health Best Western Premier Hotel, Solo, Indonesia, October 23-24, 2019 | 50 